DARIUSZ KUBINOWSKI

\author{
UNIWERSYTET SZCZECIŃSKI
}

http://dx.doi.org/10.18778/8142-715-9.04

\title{
Metodologia badań pedagogicznych między normatywnością a opisowością
}

\section{Uwagi wstępne}

Metodologia badań pedagogicznych stanowi dziś rozległy i stale rozwijany obszar wiedzy o metodach działalności badawczej na gruncie pedagogiki jako dyscypliny naukowej oraz w różnych kontekstach tej swoistej aktywności poznawczej. Mimo że wiedza ta jest konstruowana od momentu zaistnienia pedagogiki naukowej, kiedy to na początku XIX wieku wydzieliła się ona z filozofii (Lewowicki, 2006, s. 19), oraz nieustannie wzbogacana i aktualizowana aż do naszych czasów, odnoszę wrażenie, że w rodzimym pedagogicznym środowisku naukowym nadal nie doczekaliśmy się fundamentalnych dla tożsamości dyscyplinarnej uzgodnień co do istoty trzech kluczowych jej kategorii, a mianowicie: pedagogiczności badań naukowych, zakresu badań pedagogicznych i wreszcie samej metodologii jako takiej, oczywiście w odniesieniu do pedagogiki jako dyscypliny naukowej i badań pedagogicznych w szczególności. Może to wynikać z faktu, że pedagogika polska, bazująca na rodzimych tradycjach i oryginalnych podejściach, rozwija się w ścisłym powiązaniu z dorobkiem myśli i badań pedagogicznych/ edukacyjnych na świecie, starając się hybrydycznie wykorzystywać i adaptować tradycje i dokonania pedagogiki niemieckiej, angloamerykańskiej, frankofońskiej i wielu innych kręgów kulturowo-językowych. Z jednej strony stan taki prowadzi do bogactwa różnych interpretacji rzeczywistości edukacyjnej/wychowawczej w zależności od preferowanych podejść i odniesień, 
z drugiej zaś stwarza naturalne podłoże do nieprecyzyjności, niejednoznaczności, a przez to potencjalnych nieporozumień w zakresie podstawowych kategorii metodologicznych.

Przedstawiony w niniejszym opracowaniu wywód ukierunkowany jest na realizację dwóch zasadniczych celów. Po pierwsze, staram się zidentyfikować, wskazać i zinterpretować różnice i rozbieżności w pojmowaniu trzech kluczowych kategorii: pedagogiczności badań naukowych, zakresu badań pedagogicznych oraz metodologii w badaniach pedagogicznych na rodzimym gruncie. Dociekaniom tym towarzyszy przywołanie autorskich prób dookreślenia ich istoty. Po drugie, staram się przedstawić i uzasadnić koncepcję metodologii badań pedagogicznych jako emergentnego obszaru wiedzy o metodach badań pedagogicznych, konstruowanego na podstawie rezultatów badań metodologicznych (badań nad badaniami), w dialektycznych i dynamicznych relacjach między normatywnością a opisowością. Konstruowanie tej wiedzy to nieustanne nadążanie za bieżącymi głębokimi przemianami społecznymi i permanentne podejmowanie prób jej aktualizowania jako reakcji na niesłychaną ich dynamikę w XXI wieku.

\section{Permanentne kontrowersje dotyczące pojmowania trzech kluczowych kategorii metodologii badań pedagogicznych}

Analizując opracowania, stanowiska i propozycje metodologów badań pedagogicznych oraz badaczy pedagogicznych na rodzimym gruncie (także związanych ze środowiskiem Seminariów Metodologii Pedagogiki Polskiego Towarzystwa Pedagogicznego), od dawna identyfikuję raczej niezmienne i permanentne kontrowersje wokół pojmowania trzech kluczowych dla tego obszaru wiedzy, a także jej bieżącego konstruowania, kategorii metodologicznych. Można wobec tego sformułować pytania (które być może nie okażą się retoryczne) o ich wykładnię, przyjmowane uzasadnienia oraz przywoływane argumenty na rzecz takiego, a nie innego stanowiska. Dotyczą one, po pierwsze, pedagogiczności badań naukowych, po drugie, zakresu badań pedagogicznych, po trzecie, istoty metodologii w badaniach pedagogicznych. Pokrótce scharakteryzuję sens zidentyfikowanych kontrowersji, a następnie przedstawię i uzasadnię własne stanowisko w odniesieniu do powyższych pytań, przywołując wcześniejsze moje publikowane opracowania na ten temat. W tym miejscu nie podejmuję krytyki różnych stanowisk, szanując zasadę pluralizmu metodologicznego, i ograniczam się do zasygnalizowania zidentyfikowanej kontrowersji oraz zaprezentowania wyłącznie własnego punktu widzenia, poddając je ewentualnej krytyce innych metodologów i badaczy pedagogicznych. 


\section{Pytanie o pedagogiczność badań naukowych}

Pierwsza ze zidentyfikowanych przeze mnie kontrowersji w polskim dyskursie metodologicznym dotyczącym badań pedagogicznych polega na nierozstrzygniętych dotąd sporach o to, czy istnieje coś takiego jak naukowa swoistość badań pedagogicznych, a jeśli istnieje, to na czym ona polega w porównaniu do badań naukowych prowadzonych na gruncie innych dyscyplin nauk humanistyczno-społecznych. W metodologii badań pedagogicznych (różnie uprawianej) formułowane są dwie przeciwstawne odpowiedzi na tak postawione pytanie. Pierwsza z nich głosi, że takowa swoistość nie istnieje, a pedagogika jest jedną z nauk o wychowaniu/edukacji, niewyróżniającą się niczym szczególnym w wymiarze metodologicznym od innych nauk humanistyczno-społecznych, gdyż wykorzystuje analogiczne metody badawcze i stosuje się do tzw. ogólnych kryteriów wszelkich przejawów poznania naukowego. Zgodnie z drugą zaś istnieje coś takiego jak pedagogiczność badań naukowych - czy inaczej: naukowa swoistość badań pedagogicznych - nie tylko w wymiarze przedmiotowym, ale przede wszystkim w metodologicznym, co zasadniczo odróżnia je od wszelkich innych przejawów poznania naukowego, niezależnie od osadzenia dyscyplinarnego.

Osobiście uważam, że w naukach o człowieku istnieje coś takiego jak pedagogiczność badań naukowych nad wychowaniem/edukacją. Argumenty na rzecz takiego stanowiska przedstawiłem szerzej przede wszystkim w opracowaniu zatytułowanym Wychowanie i jego konteksty w perspektywie pozapedagogicznej i pedagogicznej (2008), opublikowanym w jednym z tomów w ramach serii Seminariów Metodologii Pedagogiki Polskiego Towarzystwa Pedagogicznego. Niezmiennie uważam, że swoistość badań pedagogicznych jako badań naukowych wynika z dwóch nakładających się na siebie warunków, traktowanych jednocześnie jako prymarne kryteria ich krytyki metodologicznej. Oznacza to, że za naukowe badania pedagogiczne uznać można jedynie te, które dotyczą wychowania/edukacji lub jego/jej kontekstów i są realizowane z zastosowaniem perspektywy pedagogicznej. Perspektywa pedagogiczna oznacza prowadzenie badań naukowych nad wychowaniem/edukacją lub jego/jej kontekstami na trzech nakładających się na siebie poziomach analityczno-interpretacyjnych. Pierwszym z nich są opis, interpretacja oraz rozumienie/wyjaśnianie wychowania/edukacji i jego/jej kontekstów przy użyciu metod poznania naukowego, drugi stanowi wartościowanie humanistyczne tak określonego przedmiotu badań, a trzeci odnosi się do kategorii potencjalności rozwoju człowieka/ludzi i kreowania lepszego świata jego/ich życia w odniesieniu do wychowania/edukacji i jego/jej kontekstów. Krytyka metodologiczna z tak określonego punktu widzenia oznacza przede wszystkim poszukiwanie w realizowanych 
i ocenianych projektach badawczych rozwiązań i ich zastosowań, które uwzględniają te dwa kluczowe warunki. Odnoszę wrażenie, że wiele projektów badawczych realizowanych i prezentowanych przez pedagogów nie ma charakteru badań pedagogicznych w tym ich rozumieniu. Z kolei na gruncie innych niż pedagogika dyscyplin naukowych realizowane i prezentowane są projekty badawcze o takich znamionach, mimo że ich autorzy nie identyfikują ich jako pedagogicznych.

\section{Pytanie o zakres badań pedagogicznych}

Druga ze zidentyfikowanych przeze mnie kontrowersji w polskim dyskursie metodologicznym odnoszącym się do badań pedagogicznych dotyczy ich akceptowalnego zakresu oraz wynikającego z nich zestawu ich rodzajów, typów czy orientacji. Kontrowersja w tym wypadku dotyczy z jednej strony postrzegania pedagogiki jako dyscypliny naukowej łączącej synergicznie orientacje humanistyczne, społeczne i stosowane, a z drugiej - traktowanie jej wyłącznie jako dyscypliny nauk społecznych. To drugie nastawienie wyraźnie zyskało w naszym kraju na sile wraz z wprowadzeniem na mocy rozporządzenia ministerialnego osobnej dziedziny nauk społecznych, wydzielonej z dotychczasowej szeroko pojmowanej dziedziny nauk humanistycznych, i odgórne przydzielenie pedagogiki wyłącznie do nauk społecznych, co być może było uzasadnione względami administracyjno-finansowymi, ale jednocześnie stoi w zasadniczej sprzeczności z historią i istotą pedagogiki jako nauki uprawianej na świecie. Niestety rodzime środowisko pedagogiki naukowej nie okazało się (jak dotąd) na tyle silne, solidarne i skuteczne, aby efektywnie przeciwstawić się tym centralistycznym i mechanistycznym redukcjom jej statusu naukowego i - w konsekwencji - praktycznego. Orientacje humanistyczne pedagogiki polskiej w ostatnich latach wyraźnie osłabły w sytuacji konsekwentnie realizowanej opresji wobec jej wielowiekowej tożsamości naukowej. Kontrowersja tu opisywana znajduje odzwierciedlenie w przeciwstawnych stanowiskach uznanych polskich metodologów badań pedagogicznych.

Przytoczmy w tym miejscu dwie takie wyraźnie kontrastujące ze sobą opinie. Krzysztof Rubacha we wstępie do swojego podręcznika Metodologia badań nad edukacją napisał:

\footnotetext{
Nie mówimy tu o metodologii jakiejś nauki, lecz o metodologii badań nad edukacją. I nie jest to przypadek. Tę formę praktyki społecznej badają pedagodzy - najwięksi jej beneficjenci, ale także adepci psychologii i socjologii. Wszyscy oni posługują się metodologią nauk społecznych i ten podręcznik jest również na niej oparty (2008, s. 9).
}

Powstaje zasadnicza wątpliwość: Czy wobec tego edukacją i wychowaniem nie zajmowali się i nie zajmują historycy, filozofowie, antropolodzy, 
czy nie uprawiano dotąd i nie uprawia się nadal badań nad edukacją/wychowaniem z zastosowaniem metod badawczych wypracowanych i rozwijanych przede wszystkim na gruncie nauk humanistycznych? Czy wcześniej nadawane pedagogom akademickim stopnie naukowe $w$ dziedzinie nauk humanistycznych są dziś tylko ciekawostką historyczną? Jak mają się odnaleźć w dzisiejszej administracyjnej kategoryzacji humanistycznie zorientowani w swoich badaniach naukowych nad edukacja/wychowaniem uczeni, którzy nie mają wątpliwości co do niesłabnącej potrzeby i istotnych korzyści poznawczych swoich dociekań?

Marian Nowak, należący do grona współczesnych badaczy i metodologów z obszaru rodzimej (choć nie tylko) pedagogiki, zdaje się odpowiadać na te pytania w następujący sposób:

Gdy kształtowała się pedagogika, wyodrębniała się w metodologii nowa grupa nauk, która dzięki Wilhelmowi Diltheyowi (1833-1911) otrzymała specyficzny status - nauk humanistycznych (Geisteswissenschaften). Fakt ten niewątpliwie rzutował na status pedagogiki jako nauki. Pedagogika dzięki temu, mimo prób pozostawania w kręgu wiedzy medycznej czy wręcz biologicznej i koncentrowania uwagi pedagogów na podejściach zbliżonych do nauk przyrodniczych, zachowywała i wypracowywała własne podejście, jako nauka przede wszystkim humanistyczna. Jest to aktualne także dziś, gdy nie brakuje prób wpisywania pedagogiki do różnych dziedzin naukowych lub też w ogóle odmawiania jej statusu nauki (2012, s. 257).

Osobiście przychylam się do stanowiska, że pedagogika jest humanistyczno-społeczną nauką stosowaną z wszelkimi wynikającymi stąd konsekwencjami metodologicznymi. Szersze jego uzasadnienie, ze szczególnym wyeksponowaniem zagrożonej dziś humanistycznej tożsamości pedagogiki jako nauki w aspekcie metodologicznym, przedstawiłem w następujących tekstach publikowanych w tomach w serii Seminariów Metodologii Pedagogiki PTP: Pedagogiczne myślenie humanistyczne jako kategoria metodologiczna (2006), Metodologia spod znaku x2 a humanistyczna tożsamość pedagogiki (2010), Badania pedagogiczne w „kalejdoskopie” paradygmatów, orientacji, podejść, metod nauk humanistycznych, społecznych $i$ stosowanych (2017). Akceptacja takiego stanowiska oznacza uznanie całego historycznego dorobku pedagogiki jako nauki o wychowaniu/edukacji, podtrzymanie przekonania o nienaruszalnej potrzebie wieloaspektowego badania wychowania/edukacji oraz konieczności ugruntowywania i rozwijania metodologii badań pedagogicznych na pograniczu nauk humanistycznych, społecznych i stosowanych, wraz z bogactwem dotychczasowych i pojawiających się emergentnie w przyszłości adekwatnych metod poznania naukowego $w$ tej dyscyplinie. Zredukowanie jej wyłącznie do wąsko pojmowanej nauki społecznej radykalnie zubaża jej status poznawczy w konstruowaniu wiedzy o wychowaniu/edukacji. 


\section{Pytanie o istotę metodologii w badaniach pedagogicznych}

Trzecia z wyraźnie zauważalnych kontrowersji w polskim dyskursie metodologii badań pedagogicznych dotyczy istoty metodologii jako takiej. Może być ona wyrażona dwojako. Chodzi mianowicie o rozstrzygnięcie, czy metodologia pojmowana jest jako pozaparadygmatyczna metodyka badań realizowana w ramach konkretnych projektów badawczych, bez poprzedzającego etapu formułowania założeń ontologicznych, epistemologicznych, metodologicznych, czy też jako jeden z trzech (obok ontologii i epistemologii) kluczowych wymiarów przyjętego w konkretnych badaniach paradygmatu naukowego. De facto jest to pytanie o sens podtrzymywania w pedagogice jako nauce kategorii paradygmatyczności i wieloparadygmatyczności jako istotnych kryteriów krytyki metodologicznej. Towarzyszy temu w konsekwencji pytanie o to, czy we współczesnej praktyce badawczej w pedagogice mamy do czynienia i powinniśmy uznawać jedną metodologię wyabstrahowaną paradygmatycznie, czy różne metodologie osadzone w odmiennych paradygmatach.

Nie mam wątpliwości, że pedagogika jest i powinna być nauką wieloparadygmatyczną i stale otwartą oraz gotową na wykształcenie się i upowszechnienie nowych paradygmatów badawczych, lepiej dostosowanych do nieustannie i dynamicznie zmieniającej się rzeczywistości humanistyczno-społecznej. Bez świadomości metodologicznej osadzenia konkretnego projektu badawczego w określonym paradygmacie naukowym nie można mówić o niej jako o nauce dojrzałej. Projekty badawcze lekceważące paradygmatyczność i wieloparadygmatyczność przeradzają się w poszukiwania poznawcze o charakterze technicznym, instrumentalnym. Szerzej uzasadnienie takiego stanowiska przedstawiłem w monografii Idiomatyczność - synergia - emergencja. Rozwój badań jakościowych w pedagogice polskiej na przełomie XX i XXI wieku (2013, s. 67-77). Przyjęcie założenia o istnieniu różnych metodologii badań pedagogicznych oraz traktowanie ich jako konsekwencji osadzenia paradygmatycznego jest warunkiem stosowania adekwatnych kryteriów krytyki metodologicznej konkretnych projektów badawczych. W poszczególnych paradygmatach i w konsekwencji w ugruntowanych w nich metodologiach bowiem stosuje się odmienną terminologię, logikę postępowania badawczego, metodykę realizacji projektów badawczych na każdym z ich etapów, swoiste sposoby reprezentacji wyników badań i prezentacji opracowań badawczych. W poszczególnych paradygmatach, orientacjach, podejściach czy metodach badawczych zakodowana jest swoista filozofia człowieka, wobec czego przeważnie stają się one nieporównywalne, a łącznie przyczyniają się dzięki życiodajnemu poznawczo pluralizmowi metodologicznemu do konstruowania komplementarnej wiedzy o wychowaniu/edukacji i jego/ 
jej kontekstach. Stosowanie kryteriów ewaluacyjnych wyprowadzonych z odmiennego paradygmatu aniżeli ten, który zastosowano jako podstawę w danym projekcie badawczym, jest nieadekwatne, niesprawiedliwe i nieuczciwe, a przy tym przynosi - często niepowetowane - szkody społeczne i osobiste.

\section{Metodologia opisowa i normatywna}

Methodos w języku greckim oznacza „kroczenie właściwą drogą”. Metodologia badań naukowych wobec tego to wiedza o metodach poprawnego postępowania badawczego. Według Mieczysława Łobockiego metodologia badań pedagogicznych jest „nauką o zasadach i sposobach postępowania badawczego zalecanych i stosowanych w pedagogice" (2006, s. 13). W klasycznym już dziś ujęciu metodologię można zatem uprawiać na dwa sposoby, a mianowicie jako naukę opisową i normatywną. Stefan Nowak opisał je następująco:

Przy opisowym podejściu w metodologii poddajemy analizie metody postępowania badawczego charakterystyczne dla danej dyscypliny czy dla pewnego rodzaju problemów w sposób czysto rejestrujący, bez odnoszenia się do jakichś normatywnych standardów służących do ich oceny. [...] Takie opisowe podejście może być właściwe wtedy, kiedy przedmiotem badań jest nauka sama, traktowana jako element ludzkiej kultury [...], czyli kiedy celem jest opis nauki takiej, jaka ona jest. Patrząc na naukę z tej czysto opisowej perspektywy, o jej metodach badawczych możemy co najwyżej powiedzieć, iż stosując je lub zalecając innym do stosowania, badacze sądzili lub sądzą, iż są one właściwymi sposobami postępowania w odpowiednich sytuacjach. [...] O tym, jak te czynności realizować w sposób poprawny, mówią reguły metodologiczne, których zasadność uznajemy. Kiedy reguły te stosujemy jako kryteria oceny nauki istniejącej lub jako normy własnego postępowania badawczego i wzorce pożądanego kształtu jego wytworów, przechodzimy na teren metodologii pojmowanej w sposób opisowy (2012, s. 23-24).

W odniesieniu do metodologii badań pedagogicznych Łobocki przedstawił te dwa sposoby jej uprawiania tak:

[...] Można mówić o uprawianiu metodologii badań pedagogicznych niejako na dwa sposoby, tj. metodologii uprawianej w opisowy i normatywny sposób. W pierwszym przypadku mamy do czynienia z metodologią jako nauką opisową, zajmującą się głównie opisem i analizą przeprowadzonych dotychczas badań pedagogicznych z punktu widzenia zastosowanych podczas nich zasad i sposobów postępowania badawczego. W drugim zaś przypadku, tj. metodologii pojmowanej w sensie normatywnym, chodzi o metodologię, która zajmuje się zasadami i sposobami postępowania badawczego w znaczeniu postulatywnym, czyli formułowaniem teoretycznych założeń czy przesłanek istotnych dla badań pedagogicznych (2003, s. 14-15).

Takie rozumienie metodologii badań naukowych, oparte na rozdzielnym traktowaniu metodologii opisowej i normatywnej, może rodzić szereg kolejnych kontrowersji, ale jednocześnie pozwala na skonstruowanie modelu całościowo, komplementarnie pojmowanej koncepcji metodologii nauk 
humanistyczno-społecznych, w tym pedagogicznych, jako wiedzy stale aktualizowanej, bo dostosowywanej do zmiennej sytuacji kulturowej.

Wobec powyższego proponuję, aby metodologia badań pedagogicznych pojmowana była i uprawiana jako nauka empiryczno-filozoficzna/ filozoficzno-empiryczna nastawiona na emergentne konstruowanie stale aktualizowanej wiedzy o metodach badań pedagogicznych na podstawie rezultatów pedagogicznych badań metodologicznych (badań nad badaniami) w diachronicznych i dialektycznych relacjach między normatywnością a opisowością, co odzwierciedlać ma starania uczonych na rzecz poznawczego nadążania za bieżącymi przemianami społeczno-kulturowymi. Akceptacja tej propozycji oznacza negację stabilności metodologii normatywnej, w naukach społecznych przede wszystkim opartej na założeniach paradygmatu pozytywistycznego oraz nastawieniach scjentystycznych. Jednocześnie odpowiada ściśle zasadzie paradygmatyczności uprawiania badań naukowych oraz pojmowania pedagogiki jako nauki wieloparadygmatycznej, stale otwartej na generowanie nowych, adekwatnych w stosunku do dynamicznie zmiennej w XXI wieku rzeczywistości humanistyczno-społecznej. Stanowi istotne wyzwanie wobec metodologów i badaczy pedagogicznych, gdyż podważa ich nieuzasadnione empirycznie przekonanie, że można posłużyć się metodami badań stosowanymi dawniej na zasadzie rzemieślniczej reprodukcji niezależnie od podejmowanego tematu, analizowanego przedmiotu czy rozwiązywanego problemu badawczego. Metodyka badań pedagogicznych musi stale ewoluować, bo stale zmienia się rzeczywistość wychowania/edukacji człowieka. Stąd metodologia badań pedagogicznych musi być zasobem wiedzy naukowej o metodach poznania naukowego nieustannie i adekwatnie aktualizowanym z poszanowaniem zasady harmonii między tradycją a kreatywnością metodologiczną. W przeciwnym wypadku stanie się ona zbiorem abstrakcyjnych reguł i kryteriów nieprzystających do aktualnej sytuacji kulturowej, a tym samym przerodzić się może w pozór uprawiania badań naukowych li tylko na mocy feudalnego autorytetu akademii.

Przytoczmy tu jakże trafne i odważne sformułowania psychologa twórczości Stanisława Popka na temat różnych metod badań społecznych, które mogą stanowić drogowskaz dla wszystkich ambitnych i równie odważnych badaczy pedagogicznych, a także ważną przestrogę dla ortodoksyjnych recenzentów prac naukowych, dla których pozytywistyczna socjalizacja stała się uświadomioną bądź nieuświadomioną barierą na drodze do nieuniknionej i życiodajnej kreatywności metodologicznej w nauce. Badacz stwierdził mianowicie, że twórczość naukową można ulokować na kontinuum między twórczością rzemieślniczą a wizjonerską. Ta pierwsza jest naśladowcza, sprawdzająca znane wyniki badań, wtórna, subiektywna. Druga zaś jest kreacyjna, wytwarzająca nowe hipotezy teoretyczne i empiryczne, tworząca nowe modele teoretyczne, wytwarzająca nowe metody i narzędzia 
badawcze, zobiektywizowana. Pierwsza mało wnosi w rozwój nauki, druga - ma dużą wartość perspektywiczną w jej rozwoju. Pierwsza jest bardzo poprawna metodologicznie, druga zaś - często nie jest na wstępnych etapach. Pierwsza jest na ogół jest wysoko oceniana przez recenzentów, druga - na ogół nisko (Popek, 2012, s. 187). Po uświadomieniu sobie tych trafnie i obrazowo wykazanych różnic w uprawianiu badań humanistyczno-społecznych każdy uczony niech sam sobie odpowie, czy czuje się i chce być bardziej rzemieślnikiem, czy wizjonerem, a recenzenci może zechcą uwzględnić tę jakże odkrywczą diagnozę w trakcie podejmowania ostatecznych decyzji przy ocenianiu osiągnięć naukowych „rzemieślników” i „wizjonerów" badań pedagogicznych.

Jedną z fundamentalnych kategorii metodologicznych w badaniach humanistyczno-społecznych, w tym pedagogicznych, stała się na początku XXI wieku emergencja. Chodzi tu o trzy rodzaje emergencji wzajemnie od siebie uzależnione, a mianowicie: globalną, metodologiczną i metodyczną. Sharlene Nagy Hesse-Biber i Patricia Leavy wskazały, że turbulentne środowisko społeczne, polityczne, ekonomiczne staje się czynnikiem innowacji epistemologicznych w naukach humanistyczno-społecznych, co z kolei prowadzi do innowacji teoretycznych i metodologicznych. Oznacza to, że emergencja globalna, rozumiana jako nieustanne, gwałtowne zmiany dokonujące się w kulturze ludzkiej w skali całego świata, wymusza kreatywność epistemologiczną i metodologiczną uczonych. Mimo to zawsze pojawiać się będzie naturalny dystans czasowy w stosunku do możliwości poznawczego, naukowego uchwycenia i zaprezentowania szerszej publiczności opisów i interpretacji nowych procesów i zjawisk społecznych. Rezultatem tego przesunięcia temporalnego jest luka metodyczna, czyli krótkotrwały brak adekwatnej metody badawczej pozwalającej na poznanie i opisanie owych procesów i zjawisk. Jednak przeważnie udaje się przełamać te bariery poznawcze i za pomocą nowych paradygmatów, orientacji, podejść i metod bądź innowacyjnej adaptacji tych dotychczas stosowanych efektywnie wprowadzić do praktyki badawczej nowe rozwiązania metodyczne. $Z$ metodologicznego punktu widzenia istotne jest to, że tej działalności towarzyszy nieustannie renegocjacja zasad realizacji i kryteriów krytyki całego procesu badań naukowych (Hesse-Biber, Leavy, 2008, s. 3).

\section{Pedagogiczne badania metodologiczne}

Aby możliwe było spełnienie warunku diachronicznych i dialektycznych relacji między metodologią normatywną i opisową oraz pogodzenie emergencji globalnej, metodologicznej i metodycznej w pedagogice jako nauce, niezbędne jest upowszechnianie, uprawianie i rozwijanie badań metodologicznych. Określenie „badania metodologiczne” może wydać 
się kontrowersyjne chociażby ze względu na to, że metodologia jest nauką o metodach badawczych. Jednak jeżeli potraktujemy ją jako naukę empiryczną, a za taką jej wersją zdecydowanie się opowiadam w niniejszym opracowaniu, to badania metodologiczne w pedagogice stanowią szczególny rodzaj empirycznych badań nad badaniami realizowanych na gruncie pedagogiki. Tak pojmowane, mają one na celu przede wszystkim permanentną aktualizację stanu wiedzy o nowych metodach badawczych, adekwatnie i emergentnie dostosowanych do zmieniającej się dynamicznie rzeczywistości humanistyczno-społecznej, oraz w rezultacie - krytyczną ich analizę, rewidowanie i rekonfigurowanie dotychczas obowiązujących zasad i kryteriów poprawnościowych metodologii normatywnej. Wyraźnie wynika z tej koncepcji postulat uwzględniania w dokonywanych ocenach realizowanych aktualnie projektów badawczych reguły temporalnej względności stosowanych kryteriów owej ewaluacji. Nie są to oczywiście kryteria zupełnie nowe, ale otwarte na nieuniknioną i pożądaną innowacyjność i kreatywność w celu doskonalenia sposobów poznania naukowego.

Pedagogiczne badania metodologiczne obejmują przede wszystkim historię badań naukowych w pedagogice, ze szczególnym uwzględnieniem rozwoju poszczególnych tradycji i metod badawczych na tle porównawczym (transdyscyplinarnym), analizę i krytyczną interpretację podręczników z zakresu metodologii badań pedagogicznych, ze szczególnym uwzględnieniem zagadnienia źródeł komponentów metodologii normatywnej w pedagogice, mapowanie praktyk badawczych zrealizowanych w ramach konkretnych projektów badań pedagogicznych, ze szczególnym uwzględnieniem ich krytyki metodologicznej, badanie różnorodnych uwarunkowań prowadzenia badań pedagogicznych w ujęciu kontekstualnym, uprawianie różnych form konstruktywnej krytyki metodologicznej w pedagogice z zachowaniem standardów etycznych oraz przeprowadzanie różnorodnych doświadczeń i eksperymentów metodologicznych intencjonalnie nastawionych na testowanie różnych aspektów całościowo rozumianej metodyki badań pedagogicznych. Pośród tematów badań metodologicznych w pedagogice można wymienić przykładowo historyczne rekonstruowanie trajektorii legitymizacji naukowej poszczególnych metod badawczych (np. badań w działaniu od metody uznawanej początkowo za nienaukową, przez stopniową jej formalizację metodyczną, aż do uznania jej naukowości na początku XXI wieku, albo autoetnografii, która obecnie dopiero aspiruje do uznania za w pełni naukową na gruncie nauk społecznych, w tym pedagogiki). Interesujące jest także dociekanie źródeł i przejawów rozbieżności czy wręcz sprzeczności w konstruowaniu i modyfikowaniu zaleceń i ustaleń metodologii normatywnej w badaniach pedagogicznych na podstawie studiowania podręczników metodologicznych, wypowiedzi metodologów i badaczy oraz raportów z badań (np. spory o istotę nauki i różnice w jej pojmowaniu w naukach społecznych, zróżnicowane aksjomaty przyjmowane na gruncie 
poszczególnych paradygmatów, koncepcje autorskie metodologii normatywnej i opisowej, sankcjonowanie wniosków z doświadczania praktyk badawczych, kreatywność metodyczna).

\section{Uwaga końcowa}

Normatywność i opisowość w metodologii badań pedagogicznych wzajemnie się dopełniają i synergicznie na siebie oddziałują. Ugruntowane tradycje metodologii normatywnej w pedagogice jako humanistyczno-społecznej nauce stosowanej wyznaczają kierunki realizacji projektów badawczych, których analizowanie i krytyczna interpretacja stają się podstawą konstruowania i aktualizowania metodologii opisowej. Wnioski z tych badań metodologicznych na zasadzie sprzężenia zwrotnego wykorzystywane są do rewizji i wzbogacenia metodologii normatywnej. Trudno jest jednoznacznie stwierdzić, czy prymarne są wobec tego ustalenia metodologii normatywnej, czasami wyabstrahowane z uwarunkowań praktyk badawczych, czy też to rezultaty badań metodologicznych współokreślające metodologię opisową przyczyniają się do tworzenia norm poprawnościowych w ramach metodologii normatywnej. Nie ulega jednak wątpliwości, że tak jak dynamicznie zmienia się przedmiot badań pedagogicznych, tak samo dynamicznie winna zmieniać się na zasadzie aktualizacji zarówno metodologia opisowa, jak i normatywna w pedagogice. Mam nadzieję, że postulat ten brany jest pod uwagę jako kluczowe uwarunkowanie wszelkiej konstruktywnej krytyki metodologicznej w praktyce tworzenia wiedzy pedagogicznej.

\section{Bibliografia}

Hesse-Biber, S.N., Leavy, P. (2008). Pushing on the Methodological Boundaries. The Growing Need for Emergent Methods Within and Across the Disciplines (s. 1-15). W: S.N. Hesse-Biber, P. Leavy (eds.), Handbook of Emergent Methods. New York-London: The Guilford Press.

Kubinowski, D. (2006). Pedagogiczne myślenie humanistyczne jako kategoria metodologiczna (s. 171-180). W: D. Kubinowski, M. Nowak (red.), Metodologia pedagogiki zorientowanej humanistycznie. Kraków: Oficyna Wydawnicza „Impuls”.

Kubinowski, D. (2008). Wychowanie i jego konteksty w perspektywie pozapedagogicznej i pedagogicznej (s. 47-56). W: K. Rubacha (red.), Konceptualizacje przedmiotu badań pedagogicznych. Kraków: Oficyna Wydawnicza "Impuls”.

Kubinowski, D. (2010). Metodologia spod znaku X2 a humanistyczna tożsamość pedagogiki (s. 79-90). W: J. Piekarski, D. Urbaniak-Zając, K.J. Szmidt (red.), Metodologiczne problemy tworzenia wiedzy w pedagogice - oblicza akademickiej praktyki. Kraków: Oficyna Wydawnicza „Impuls".

Kubinowski, D. (2013). Idiomatyczność - synergia - emergencja. Rozwój badań jakościowych w pedagogice polskiej na przełomie XX i XXI wieku. Lublin: Makmed. 
Kubinowski, D. (2017). Badania pedagogiczne w „kalejdoskopie” paradygmatów, orientacji, podejść, metod nauk humanistycznych, społecznych i stosowanych (s. 15-24). W: D. Kubinowski, M. Chutorański (red.), Pedagogika jako humanistyczno-społeczna nauka stosowana - konsekwencje metodologiczne. Kraków: Oficyna Wydawnicza „Impuls".

Lewowicki, T. (2006). Szkic do dziejów metodologii pedagogiki (s. 17-27). W: D. Kubinowski, M. Nowak (red.), Metodologia pedagogiki zorientowanej humanistycznie. Kraków: Oficyna Wydawnicza "Impuls".

Łobocki, M. (2003). Wprowadzenie do metodologii badań pedagogicznych. Kraków: Oficyna Wydawnicza "Impuls".

Łobocki, M. (2006). Metody i techniki badań pedagogicznych. Kraków: Oficyna Wydawnicza „Impuls".

Nowak, M. (2012). Pedagogiczny profil nauk o wychowaniu. Studium z odniesieniami do pedagogiki pielęgniarstwa. Lublin: Wydawnictwo KUL.

Nowak, S. (2012). Metodologia badań społecznych. Warszawa: Wydawnictwo Naukowe PWN.

Popek, S. (2012). Męka tworzenia - reguła czy wyjątek? Rocznik Pedagogiczny. Numer specjalny z okazji XXV-lecia LSMP pod patronatem KNP PAN, 177-196.

Rubacha, K. (2008). Metodologia badań nad edukacją. Warszawa: Wydawnictwa Akademickie i Profesjonalne.

\title{
Methodology of pedagogical research between normativity and descriptivity
}

\begin{abstract}
SUMMARY
The author tries to identify, present and explain permanent controversies concerning three key methodological categories used in the methodology of pedagogical research in Poland: "pedagogical dimension" of scientific research; scope of pedagogical research; and methodology in pedagogical research. The author describes the nature of the controversy and emphasizes his own approach to it. The main aim of the chapter is to propose the author's own concept of understanding the methodology of pedagogical research as philosophical-empirical science that is built and being constantly rebuilt in diachronic and dialectic relationships between normative and descriptive methodologies, as an emergent reaction to radical and dynamic changes of a social reality. The author emphasizes the important role of methodological research ("research on research") in constructing new scientific knowledge in the field of methodology of pedagogical research.
\end{abstract}

Keywords: methodology of pedagogical research, normativity, descriptivity, methodological research; global, methodological and methodical emergences 